\title{
ASSESSMENT OF THE IMPACTS OF BUSINESS ENVIRONMENT ON THE DEVELOPMENT OF VIETNAMESE SMEs: EVIDENCE FROM THE ENTERPRISE SURVEY
}

\author{
Nguyen Quoc Dinh ${ }^{\mathrm{a}^{*}}$ \\ ${ }^{a}$ The Southern Institute of Social Sciences, Vietnam Academy of Social Sciences, Hanoi, Vietnam \\ ${ }^{*}$ Corresponding author: Email: quocdinhnguyen2011@gmail.com \\ Article history \\ Received: October 12 ${ }^{\text {th }}, 2017 \mid$ Received in revised form: December $15^{\text {th }}, 2017$ \\ Accepted: February $6^{\text {th }}, 2018$

\begin{abstract}
Many studies have shown that a firm's growth depends considerably on business environment. In this study, the employment growth of SMEs in Vietnam is investigated with respect to its crucial role in the entire economy. The results of the regression analysis of fixed-effect model show that informal payment, low institution quality, and tax inspections are hindering the employment growth of SMEs in Vietnam, while expanding the access to finance can help SMEs develop. Based on the rigorous analysis, some possible recommendations are provided: (i) Expanding application of information technology in tax administration; (ii) Reducing complicated sub-licenses and administrative procedures; (iii) Reducing business risks of firms by establishing a specific business strategy and long-term vision; and (iv) Decreasing the chances of corruption by simplifying and rationalizing the regulatory loopholes as well as increasing transparency in making laws/policies.
\end{abstract}

Keywords: Business environment; Fixed-effect model; SMEs; Vietnam Enterprise Survey.

Article identifier: http://tckh.dlu.edu.vn/index.php/tckhdhdl/article/view/350

Article type: (peer-reviewed) Full-length research article

Copyright () 2018 The author(s).

Licensing: This article is licensed under a CC BY-NC-ND 4.0 


\section{INTRODUCTION}

"Environment" literally means the surroundings, external objects, influences, or circumstances under which someone or something exists (Shaikh, 2010). Jauch and William (1988) define the business environment as the aggregate of all external and internal conditions which directly or indirectly impact the activities of an enterprise. Some recent studies have attempted to narrow the concept of business environment, assuming that business environment is primarily the policies and regulations that the government applies to regulate operations of enterprises (VCCI, 2008), or the business environment at a given location is the cumulative outcome of policies at all levels of geography (Porter, 2010).

The World Bank (2005a) also provides a definition of business environment that comprises a number of specific factors that shape opportunities and incentives for enterprises to invest effectively, create jobs, and expand their activities. Factors in the business environment are divided into two groups: Operating factors, consisting of political and macroeconomic stability, the legal system, regulations, corruption, competition degree; and Infrastructure factors, including infrastructure and financial systems. This study focuses on some specific factors, especially administrative procedures, corruption and informal payment, and tax administration. These factors are examined in relation to the labor growth rate of enterprises. This study does not cover all aspects of business environment, such as macroeconomics or political stability.

Business environment has tremendously impacted the development of enterprises (Seker \& Correa, 2010; Vũ, 2015; VCCI, 2015; \& CIEM, 2016). At the firm level, it directly influences costs of production; At the industry level, it often relates to market structure and competition (Eifert, Gelb, \& Ramachandran, 2005). Nevertheless, the World Bank (2016) shows that Vietnam's business environment remains in a low-middleranked group, ranking 82 out of 189 countries, based on 11 criteria in which there are some very low-ranked ones, such as business establishment (ranked 121), tax payment (ranked 167), and bankruptcy procedures (ranked 125). The low-ranked business environment has negatively impacted on the development of Vietnamese enterprises, 
especially in the private sector, which has contributed significantly to the economy. In 2007-2015, enterprises in Vietnam experienced a 7.4\% increase in employment growth rate, equal to half of the firm growth rate, that has resulted in the decrease in the size of enterprises, from an average 49 employees in 2007 to only 29 employees in 2015, particularly in the private sector, decreasing from 27 employees to nearly 18 employees in the same period (VCCI, 2015). Meanwhile, state-owned enterprises have contributed modestly to the development of the country in spite of substantial resources they have gained from favorable policies (Vũ, 2015).

This study aims to investigate the factors that are truly influencing employment growth of firms in Vietnam with an emphasis on small and medium-sized enterprises (SMEs). SMEs in Vietnam play a crucial role in economic development. They account for $95 \%$ of businesses, contributing approximately $45 \%$ of GDP, $31 \%$ of total revenue and about $35 \%$ of total investment capital, generating over 5,000,000 workers and contributing nearly 50\% to the annual economic growth (VCCI, 2015). Moreover, a strong and vibrant SME sector is important to the recovery of the economy from economic crises. In addition, Vietnam is facing the "missing middle", a shortage of medium-sized enterprises that has not enabled Vietnam to reach a higher place in the global value chains.

More importantly, Vietnam is facing serious challenges from its aging population, climate change, and low productivity that are dramatically diminishing the quality of growth which can be understood as to reduce extreme poverty, narrow structural inequalities, protect the environment, and sustain the growth process itself (López, Thomas, \& Wang, 2008). Given this, the development of the private sector can minimize these challenging issues. To do this, identification of factors that are hindering the development of SMEs is really important because policies to enhance SMEs are efficient only when we can identify precisely what factors are restraining them.

The rest of the paper is organized as follows. Section 2 provides a literature review on the impacts of business factors on SMEs in various countries. Section 3 explains the data. Section 4 elaborates on analyzing downward trends of employment through the 
description of data and effects of business environment on SMEs through regression analysis. Finally, Section 5 provides concluding remarks and policy recommendations.

\section{LITERATURE REVIEW}

The literature has described the business environment factors that support enterprises to grow which are institutional quality, control of corruption and informal payment, tax administration, access to credit, and infrastructure (Aterido \& Hallwarddriemeier, 2009; Barlett \& Bukvic, 2001; Baurer, 2005; Beck, Demirguc, \& Maksimovic, 2005; Fisman \& Svensson, 2007; Kauffmann, 2005; Kato \& Sato, 2014; \& Kumar, Rajan, \& Zingales, 1999). Institutional quality is measured by the effectiveness of the government, the quality of policies and the laws, and the level of enforcement of the rules of the laws. Using business data in more than 15 European countries, Kumar et al. (1999) find a positive correlation between institutional quality and the size of firms in laborintensive industries. Bartlett and Bukvic (2001) also show that the institution, namely regulatory bureaucracy and excessive licensing requirements influence the turnover of SMEs in Slovakia. Zhu, Xinhua, and Mike (2012) identify five institutional constraints on SMEs in China including unfair competition, access to finance, laws, taxes, and other supporting institutions.

In Vietnam, obtaining operation permits have caused a large financial burden on enterprises due to numerous business registration procedures and conditional business licenses (sub-licenses). Vietnamese enterprises have to pay more to ensure their operations run smoothly. As a result of low institutional quality, the entry costs in Vietnam are always high (VCCI, 2015). The situation is relatively similar in Indonesia and Malaysia, except for Thailand and the Philippines.

Informal payment is undocumented money that firms have to pay to public officials in order to operate their business smoothly without interruption. Informal payment is a specific manifestation of corruption. Corruption is the abuse of state power

for personal gain (World Bank, 2000). However, the impacts of corruption and informal payment on the development of firms do not follow the same patterns. Previous studies 
show that informal payments for public services will help businesses operate more smoothly, especially in developing countries because such payments provide incentives for civil servants to work more responsibly. Vial and Hanoteau (2014) find a positive impact of corruption on labor productivity growth in Indonesia. In contrast, Krueger (1993) finds that informal payments have reduced the company's investment in the future because previous informal payments would lead to higher demand for payments later. Mauro (1995) argues that informal payments have reduced the marginal productivity of capital and the return on investment. Firms, therefore, are reluctant to invest more. Similarly, Fisman and Svensson (2007) find a negative correlation between corruption and revenue growth in Uganda.

Data from 7,024 firms collected from the Enterprise Surveys in eight ASEAN countries to compare informal payments in Vietnam to other countries in the region reveals that one of the reasons why Vietnam's business environment is less attractive than other ASEAN countries is due to corruption in the public sector. The GIFT (Graft Index for Firm Transactions) index ${ }^{1}$ in Vietnam is 0.227 , meaning that for every 100 transactions enterprises have to pay informally nearly 23 transactions to gain access to public services. Vietnam's GIFT index is only lower than Cambodia, Myanmar, and Laos with 0.466, 0.359 and 0.346, respectively. Although the difference is not far from Malaysia (0.216), it is much higher than Thailand (0.083), the Philippines (0.145) and Indonesia (0.152).

In general, except for import licenses, the risk of corruption in 2015 was lower than in 2009, especially in construction permits. In 2009 , over $45 \%$ of transactions were conducted with informal payments in order to receive construction permits, but it had fallen to just $26 \%$ in 2015 . The same pattern was also seen in access to electricity and water with a decreasing trend fluctuating from $2 \%$ to $9 \%$. In sharp contrast, the risk of

\footnotetext{
${ }^{1}$ In order to address data limitations and differences in perceptions of corruption, Gonzalez, López-Córdova, and Valladares (2007) have developed a corruption index for business transactions, called GIFT as following formula: $G I F T_{k}=\frac{\sum_{j=1}^{6} \Sigma_{i=1}^{n_{j k}} x_{i j k}}{\sum_{j=1}^{6} n_{j k}}$

where $\mathrm{i}, \mathrm{j}$ and $\mathrm{k}$ represent company $\mathrm{i}$, transaction $\mathrm{j}$ in country $\mathrm{k}$. Binary variable $x i j k$ is set to 1 if business $\mathrm{i}$ is required to pay informal payment on transaction $\mathrm{j}$ and 0 otherwise. Denominator is the sum of transactions $\mathrm{j}$ in a country.

In other words, the GIFT index reflects the probability that an enterprise is required to pay informal payments to ensure its access to public services easily.
} 
corruption in obtaining import licenses increased by nearly 5\% from $20.77 \%$ to almost $26 \%$. Customs is another serious corrupted area beside traffic police, construction and land administration (World Bank \& The Government Inspectorate of Vietnam, 2013). A survey conducted by VCCI in 2015 shows that $64 \%$ of surveyed enterprises were afraid of being discriminated against if they did not pay more money; $86 \%$ said their goods would be delayed and $74 \%$ were required to explain and supplement additional nonregulatory documents; $39 \%$ said customs officers were not polite and badly behaved.

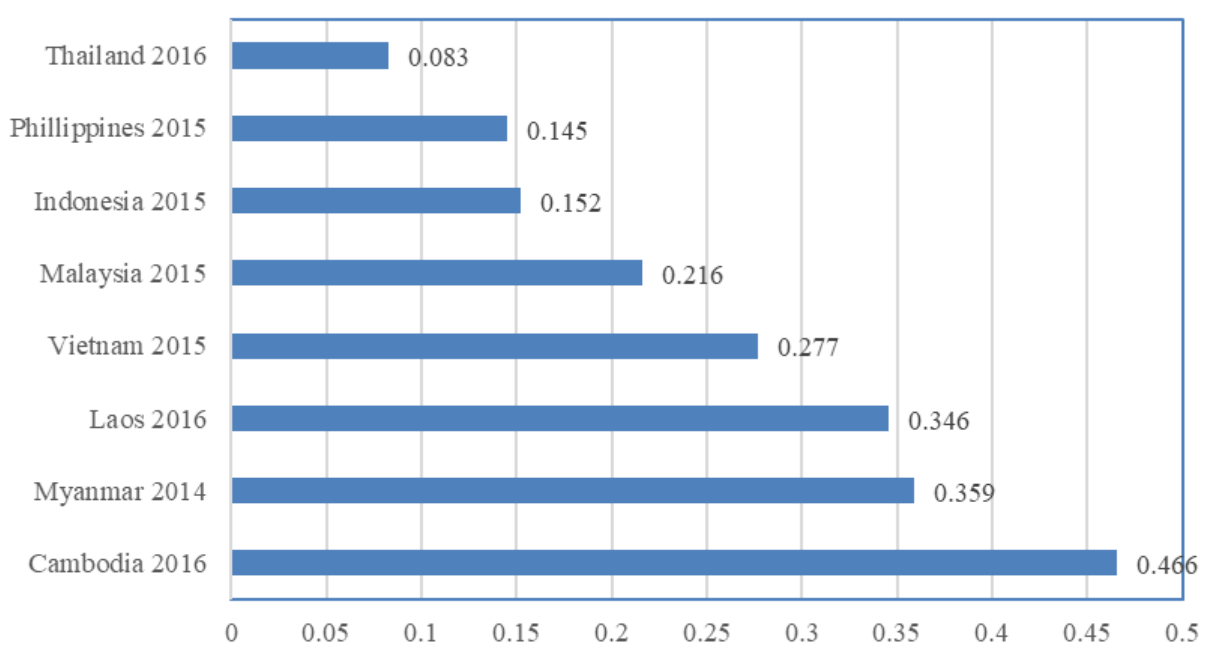

Figure 1. The GIFT Index for firm transaction in ASEAN region

Source: Author's calculation from World Bank (2015).

Tax administration is also a constraint against SMEs. Baurer (2005) shows the impact of taxation on economic growth through the development of SMEs. He argues that private firms in developing countries have been facing difficulties with tax policies and unpredictable policy changes in the future. In addition, businesses are often under pressure to comply with tax regulations being subjected to excessive checks and audits, as well as encountering dishonest tax officials and intransparent tax administration. The consequence of these problems is that businesses have to find ways to falsify reports on profits and sales, number of employees, or fabricate possible measures to reduce their tax liabilities (Ojeka \& Atawodi, 2012). The tax administration in Vietnam has the highest probability of corruption, which is significantly higher than the average level of ASEAN4 (World Bank, 2014). In fact, in Vietnam, taxes reforms have not been a priority. The World Bank's Doing Business 2015 (World Bank, 2014) reveals that Vietnamese 
businesses spend an average of 540 hours completing tax procedures with the tax rate at $39.4 \%$, while the average in other countries in the region is 198 hours with the tax rate at $33.9 \%$.

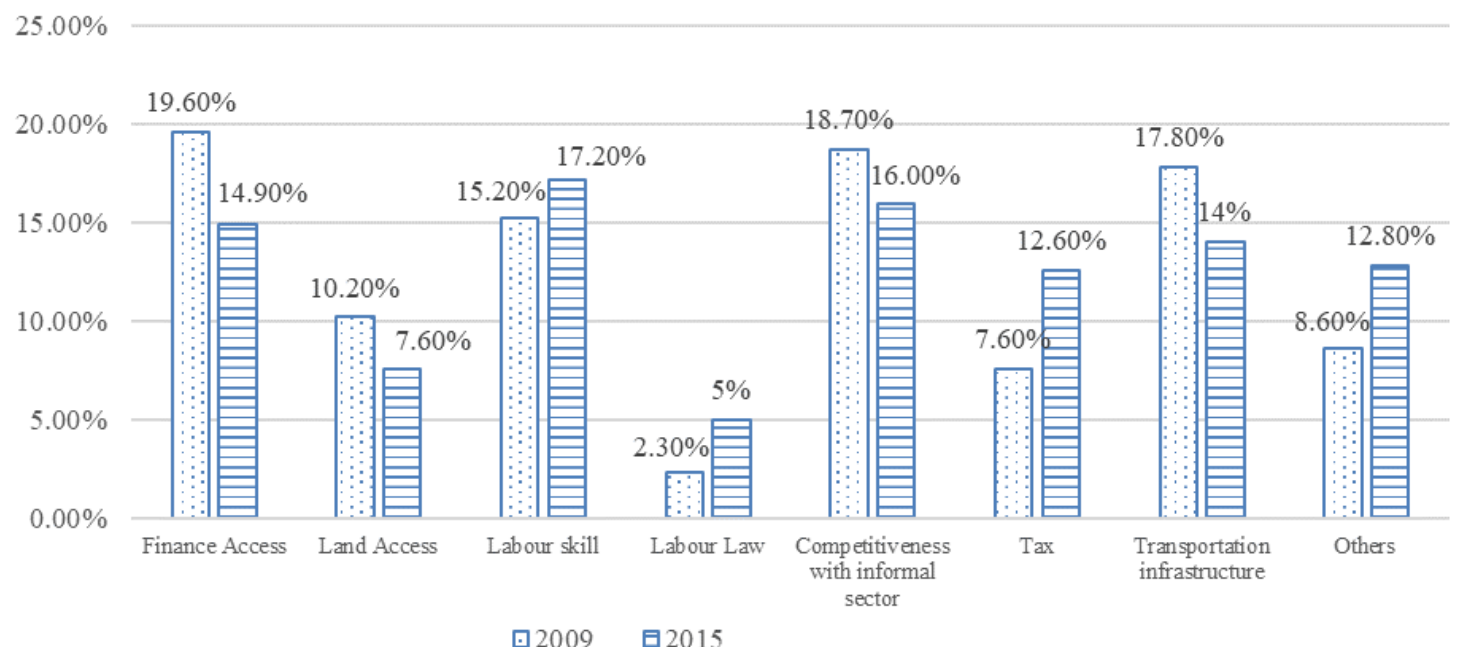

Figure 2. The most severe obstacles to enterprises in 2009 and 2015

Source: Author's calculation from World Bank (2009, 2015).

The results of the Vietnam Enterprise Surveys show that the percentage of firms that think tax is the greatest difficulty in doing business has increased by $5 \%$, from $7.6 \%$ in 2009 to $12.6 \%$ in 2015 , the highest increase compared to the other five difficulties stated in the questionnaires, including finance access and land access, skilled labors, labor laws, informal sector, and infrastructure.

In addition to high tax rates and many tax procedures, another problem is that enterprises often have to meet tax inspectors. Although the number of enterprises that had to meet with tax officers or tax inspectors has fallen dramatically from 626 enterprises in 2009 to 464 enterprises in 2015, the data in percentage has not reflected the downward trend. Table 1 shows the percentage of enterprises having met tax inspectors once or twice per year decreased slightly from $84.6 \%$ to $80.4 \%$, while the rate of enterprises with three to five contacts with tax officials grew from $11.4 \%$ to nearly $15 \%$. Thus, reducing the number of tax inspections will save time and money for enterprises and allowing them to spend these resources in production to add value to the economy. 
Access to finance is always a challenge for SMEs. A study by Seker and Correa (2010) in Turkey reveals that SMEs were unable to obtain loans due to high collateral requirement, leading to no production expansion and new access to technology. Similarly, Cooley and Quadrini (2001) argue that financial access is the foundation for business development and is the basis for business to cope with economic shocks. However, SMEs' access to loans from formal financial institutions, especially banks is rather difficult due to the general perceptions of high-risk business and cash flow management.

Table 1. The number of tax inspections by firm size

\begin{tabular}{lllllllll}
\hline $\begin{array}{l}\text { Tax } \\
\text { inspections }\end{array}$ & \multicolumn{2}{l}{$\begin{array}{l}\text { Micro \& Small } \\
\text { Enterprises }(\%)\end{array}$} & \multicolumn{2}{c}{$\begin{array}{c}\text { Medium Enterprises } \\
(\%)\end{array}$} & \multicolumn{2}{c}{$\begin{array}{c}\text { Large Enterprises } \\
(\%)\end{array}$} & \multicolumn{2}{c}{ Total (\%) } \\
\hline Year & 2009 & 2015 & 2009 & 2015 & 2009 & 2015 & 2009 & 2015 \\
\hline $1-2$ times & 18.7 & 20.5 & 33.5 & 33.8 & 32.4 & 26.1 & 84.6 & 80.4 \\
$3-5$ times & 1.3 & 3.7 & 6.7 & 5.6 & 3.4 & 5.4 & 11.4 & 14.7 \\
$>5$ times & 1.1 & 0.4 & 1.8 & 1.7 & 1.1 & 2.8 & 4.0 & 4.9 \\
\hline Total & 21.1 & 24.6 & 42.0 & 41.2 & 36.9 & 34.3 & 100.0 & 100.0 \\
\hline
\end{tabular}

Source: Author's calculation from World Bank (2015).

Infrastructure is an integrated system of transportation, electricity, water, telecommunications, etc., but this study focuses on electricity only. Energy is essential for creating jobs, manufacturing, transportation, commerce, business development and agricultural production (UNDP, 2005). The shortage of power significantly affects the production process and disrupts business activities, thus increasing the cost for businesses. Scott, Darko, and Lemma (2014)'s study in four low-income countries including Nigeria, Uganda, Bangladesh, and Nepal show that widespread outages increased the business costs due to machinery failures. Overall, the lack of electricity raises the cost of production and reduces the productivity of SMEs (Cecelski, 2004; Fjose, Grunfeld, \& Green, 2010).

The existence of many business regulations has hindered the entrepreneurial spirit and entrepreneurship and innovation in Vietnam. Annually, approximately 60,000 enterprises, equivalent to about $80 \%$ of new enterprises, leave the market, most of which are SMEs due to the severe and absurd business conditions (VCCI, 2015). The amended 
Investment Law 2014 specifies six prohibited business areas (Trafficking of humans; Human bodies and organs; Prostitution; Activities related to human cloning; Drug trafficking prescribed in Appendix 1 of the law; Trading of chemicals prescribed in Table 1 of Appendix 2 of the law; and Trading of wild plants and animals), and 267 conditional businesses at the end of 2015. Albeit conditional businesses have decreased to 243 in January 2017, there were still 7000 sub-licenses and nearly a half of those considered unreasonable and affected by over 430 different legal documents (Nguyen, 2016). Enterprises are subjected to many overlapping regulations such as Investment Law, Commercial Law, various decrees, circulars and specialized laws. These regulations have distorted the dynamics of enterprises, creating a favorable environment for nurturing corruption activities and increasing the "ask-and-give" mechanism that results in the higher operating costs for businesses. This explains why the cost of procedures and fees in Vietnam take up to $40 \%$ of corporate profits compared to the average of only $17 \%$ in ASEAN economies (VCCI, 2015).

In addition, sub-licenses also contribute to aggravate unfair competition between large and small businesses. Complicated procedures not only prevent small enterprises from entering the market but also cause small enterprises to lose the competitive advantages to large enterprises that have already met the requirements of administrative procedures as well. Furthermore, abundant sub-licenses cause the government to suffer tax losses and rising unemployment because SMEs that cannot meet the unreasonable requirements will operate in the informal sector or shut down.

\section{DATA}

Data for analysis were collected from the World Bank's Enterprise Surveys (ES). The surveys covered over 155,000 firms in 148 countries, of which 139 countries were surveyed following a standard methodology, allowing for accurate comparisons across countries and over time. The surveys were longitudinal, making it possible to track changes in the business environment over time and allow impact assessments of reforms (World Bank, 2005b). In Vietnam, there was also a comprehensive establishment level 
database, compressing 1,052 enterprises in 2009 and 996 enterprises in 2015. There were 178 firms that were both surveyed in 2009 and 2015.

In order to analyze how firms have been impacted by business environment, they were divided into four groups measured by full-time employees: Micro: $\leq 10$; Small: 11 50; Medium: 51-300; and Large: >300. These groups were constructed according to the definition of the World Bank based on the employment level of the firms, which is also adopted by the Government of Vietnam in Decree 56/2009/NO-CP (CIEM, 2016). The firms in the Vietnam Enterprise Surveys for 2009 and 2015 were selected using stratified random sampling. Three levels of stratification, namely industry, establishment size, and region were utilized. The industry stratification was designed following ISIC revision 3 in four regions: Red River Delta; North Central Area and Central Coastal Area; Southeast and Mekong River Delta.

The sample included data from food and beverages, garments, non-metallic mineral products, fabricated metal products, retails and other manufacturing and services. In two rounds of the surveys, the biggest industry in terms of number observations was food and beverage followed by garment and non-metallic mineral products. Most of the firms are located in Southeast and Red River Delta, which are the most developed and dynamic regions in Vietnam.

\section{DESCRIPTION OF DATA AND REGRESSION ANALYSIS}

SMEs in Vietnam have been experiencing a decline in the average number of employees in the period 2009-2015. The average number of employees fell from 119.77 in 2009 to 115.76 in 2015 , equivalent to a $3.3 \%$ decrease compared to 2009. Small enterprises showed the sharpest decline from 23.75 in 2009 to 20.71 employees in 2015 , a $12.8 \%$ decrease. Meanwhile, the size of microenterprises remained stable at 6.3 employees on average. The Vietnam Enterprise Surveys also showed a decrease in the employment numbers. The total number of full-time employees of 163 surveyed enterprises dropped from 8,235 to 7,941 in the period 2009-2015, approximately $3.6 \%$ of total employment as revealed in Table 2. 
The downward trend in the size of firms can also be seen in Table 3 over the same period 2009-2015. In terms of microenterprises, about $96 \%$ of enterprises in 2009 were still small (60\%) and micro (36\%) in 2015, only $4 \%$ changed into medium size. Over $60 \%$ of small and medium enterprises remained the same throughout the period, with $62.5 \%$ of small firms and $60.3 \%$ of medium firms. Only $18.8 \%$ of businesses upgraded their size from small to medium, but $31 \%$ of firms decreased from medium to small size in the same period. The downscale trend was most evident in large firms when $40 \%$ of enterprises changing from large size in 2009 to medium (26.7\%) and small (13.3\%) in 2015.

Table 2. The average number of employees by firm sizes

\begin{tabular}{|c|c|c|c|c|c|c|c|}
\hline & & \multicolumn{3}{|c|}{ Full data } & \multicolumn{3}{|c|}{ Repeated data } \\
\hline \multicolumn{2}{|l|}{ Year } & 2009 & 2013 & 2015 & 2009 & 2013 & 2015 \\
\hline \multicolumn{2}{|c|}{ Number of enterprises } & 887 & 862 & 894 & 163 & 162 & 163 \\
\hline \multicolumn{2}{|c|}{ Number of employees } & --- & --- & --- & 8,235 & 7,403 & 7,941 \\
\hline \multirow[t]{3}{*}{ Size } & Micro & $\begin{array}{l}6.29 \\
(113)\end{array}$ & $\begin{array}{l}5.88 \\
(169)\end{array}$ & $\begin{array}{l}6.32 \\
(162)\end{array}$ & $\begin{array}{l}6.48 \\
(25)\end{array}$ & $\begin{array}{l}5.68 \\
(25)\end{array}$ & $\begin{array}{l}5.65 \\
(23)\end{array}$ \\
\hline & Small & $\begin{array}{l}23.75 \\
(394)\end{array}$ & $\begin{array}{l}20.93 \\
(424)\end{array}$ & $\begin{array}{l}20.71 \\
(433)\end{array}$ & $\begin{array}{l}22.33 \\
(80)\end{array}$ & $\begin{array}{l}20.22 \\
(84)\end{array}$ & $\begin{array}{l}19.54 \\
(85)\end{array}$ \\
\hline & Medium & $\begin{array}{l}119.77 \\
(383)\end{array}$ & $\begin{array}{l}114.40 \\
(269)\end{array}$ & $\begin{array}{l}115.76 \\
(302)\end{array}$ & $\begin{array}{l}108.37 \\
(58)\end{array}$ & $\begin{array}{l}104.94 \\
(53)\end{array}$ & $\begin{array}{l}111.81 \\
(55)\end{array}$ \\
\hline
\end{tabular}

Note: Number of observations in parentheses. Source: Author's calculation from World Bank (2015).

To examine the business environment factors that have significantly influenced Vietnamese enterprises in the period 2009-2015, this section applies regression analysis using panel data from the Vietnam Enterprise Surveys. The model specification used in the regression analysis is given in Equation (1). The annual growth rate of full-time employment of firm $i$ that was surveyed in two periods 2009-2013 and 2013-2015 is presented by $g_{i t}{ }^{2}$. The dummy variables Small $_{i}$, Medium $_{i}$, and Large $_{i}$ denote the firm size. The omitted group was microenterprises to avoid the perfect multicollinearity. Age $e_{i}$ is the

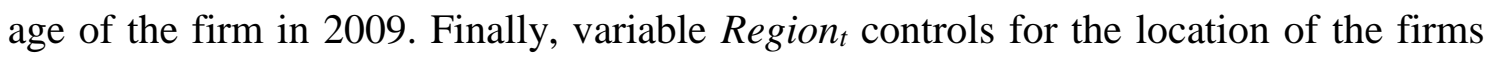

\footnotetext{
${ }^{2}$ Average annual employment growth is the change in full-time employment reported in the current fiscal year from the previous year, calculated as the formula: $\mathrm{g}=\frac{1}{t} * \frac{l_{1}-l_{2}}{\left(l_{1}+l_{2}\right) / 2} * 100 \%$ with $\mathrm{t}$ is the period between year 1 and year 2 .
} 
with the omitted north and central regions. Based on rigorous literature review, we have the equation as Equation (1).

$g_{i t}=\beta_{0}+\beta_{1}$ Finance Access $+\beta_{2}$ Collateral $+\beta_{3}$ Informal Payments $+\beta_{4}$ Time of Procedures $+\beta_{5}$ Tax Inspections $+\beta_{6}$ Power Outage/month $+\beta_{7}$ Age $+\beta_{8}$ Small +

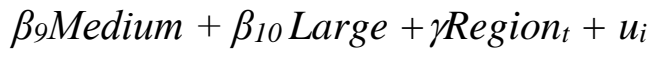

Table 3. Downward trend in the size of enterprises

\begin{tabular}{lllllll}
\hline Size & Micro 2015 & Small 2015 & Medium 2015 & Large 2015 & Total & $\%$ \\
\hline \multirow{2}{*}{ Micro 2009 } & 9 & 15 & 1 & 0 & 25 & \\
& $(36)$ & $(60)$ & $(4)$ & $(0)$ & $(100)$ & \\
Small 2009 & 14 & 50 & 15 & 1 & 80 & \\
& $(17.5)$ & $(62.5)$ & $(18.8)$ & $(1.3)$ & $(100)$ & \\
Medium 2009 & 0 & 18 & 35 & 5 & 58 & \\
& $(0)$ & $(31.0)$ & $(60.3)$ & $(8.6)$ & $(100)$ & $(32.6)$ \\
Large 2009 & 0 & 2 & 4 & 9 & 15 & \\
& $(0)$ & $(13.3)$ & $(26.7)$ & $(60.0)$ & $(100)$ & $(8.4)$ \\
Total & 23 & 85 & 55 & 15 & 178 & \\
& $(12.9)$ & $(47.8)$ & $(30.9)$ & $(8.4)$ & $(100)$ & \\
\hline
\end{tabular}

Note: Percent in parentheses.

Source: Author's calculation from the World Bank (2015).

Table 4 provides the business environment factors and the expected impact of each factor on employment growth, which were expected from the literature review. Equation (1) can be estimated with pooled regression. However, the results of pooled regression may be unreliable due to the relatively low Durbin-Watson statistics that might be related to self-correlation in the data or due to model error (Gujarati, 2003). As a result, the author utilized fixed-effects model (FE) and random-effects model (RE) to estimate the panel data. FE explores the relationship between the predictor and outcome variables within a firm. Although each firm has its own characteristics that may or may not influence the predictor variables when using FE this study aims to examine the net effect of the factors of business environment on the outcome variable (the annual employment growth of firms) (Gujarati, 2003). In other words, the effect of the time-invariant characteristics such as location, sector, the gender of managers, etc. will be removed and absorbed into $\beta_{0}$. In addition, $\mathrm{FE}$ assumes that the time-invariant characteristics are unique to the individual and should not be correlated with other individual characteristics, 
therefore the firms' error term and the constant (which captures individual characteristics) should not be correlated with the other variables (Oscar, 2007). If the error terms are correlated, FE is not suitable, hence RE seems to be more applicable. Unlike the FE model, there is an important assumption of the RE model that the variation across firms is assumed to be random and uncorrelated with the independent variables in the model. In other words, when using RE it is believed that differences across firms have some influences on the outcome variable (Oscar, 2007). The Hausman test was used to determine the appropriate model. The result of the Hausman test indicated that the p-value $<5 \%$, thus FE model was chosen.

\section{Table 4. Business environment factors}

\begin{tabular}{|c|c|c|c|}
\hline No. & Factor & How to measure & $\begin{array}{l}\text { Expected } \\
\text { impact }\end{array}$ \\
\hline 1 & Access to Finance & The proportion of working capital financed by banks & + \\
\hline 2 & Collateral & Value of collateral needed for a loan ( $\%$ of the loan amount) & - \\
\hline 3 & Informal Payments & Amount of payment/total revenue in a year & - \\
\hline 4 & $\begin{array}{l}\text { Time of Procedures } \\
\text { (Institutional quality) }\end{array}$ & $\begin{array}{l}\text { Senior management time spent in dealing with requirements } \\
\text { of government regulations in a week }\end{array}$ & - \\
\hline 5 & Tax Inspections & Tax inspections a year & - \\
\hline 6 & $\begin{array}{l}\text { Power Outage/month } \\
\text { (Electricity access) }\end{array}$ & Power outages a month & - \\
\hline
\end{tabular}

The t-test is used to test the difference between the employment growth rates in two periods 2009-2013 and 2013-2015. Because the p-value is $<5 \%$, thus $\mathrm{H}_{\mathrm{o}}$ is rejected: there is no difference between the employment growth rates in two periods 2009-2013 and 2013-2015. To assess the correctness of the model, the F-test is performed to check whether all the coefficients in the model are different from zero. The result indicates that the p-value of F-test is $0.000<5 \%$, implying that all the coefficients in the model are different from zero. In addition, the value of Rho is determined to assess whether differences across firms are correlated with the predictors. In the model Rho equals 0.772 meaning although the model is being impacted by individual characteristics, the value is still smaller than 1, therefore the level of impacts due to individual characteristics of the firms is not serious to the stability of the model. Last but not least, the R-squared is 0.66 indicating the high explanatory power of this model. Finally, the other errors of the model 
such as heteroscedasticity, serial correlation and multicollinearity are corrected for. The regression results are reported in Table 5.

Table 5. FE model of business environment factors

\begin{tabular}{|c|c|c|c|c|}
\hline & \multirow[t]{2}{*}{ beta } & \multirow[t]{2}{*}{ Standard Error } & \multicolumn{2}{|c|}{$95 \%$ of Confidence Interval } \\
\hline & & & Upper & Lower \\
\hline \multicolumn{5}{|l|}{ Independent variables } \\
\hline Finance Access & $0.003 * *$ & 0.002 & 0.000 & 0.006 \\
\hline Collateral & -0.019 & 0.018 & -0.053 & 0.015 \\
\hline Informal Payments & $-0.025 * *$ & 0.011 & -0.049 & -0.001 \\
\hline Time of Administrative Procedures & $-0.013 * *$ & 0.003 & -0.021 & -0.005 \\
\hline Tax Inspections & $-0.027 * *$ & 0.015 & -0.054 & 0.000 \\
\hline Power Outage/month & 0.003 & 0.002 & -0.001 & 0.008 \\
\hline \multicolumn{5}{|l|}{ Control variables } \\
\hline Age & $-0.026^{* *}$ & 0.007 & -0.041 & -0.010 \\
\hline Small & -0.013 & 0.017 & -0.031 & -0.015 \\
\hline Medium & $0.020^{*}$ & 0.010 & -0.01 & -0.021 \\
\hline Large & $0.015^{*}$ & 0.011 & -0.041 & 0.010 \\
\hline Red River Delta & 0.015 & 0.012 & -0.031 & -0.001 \\
\hline Southeast Region & 0.021 & 0.017 & -0.210 & 0.102 \\
\hline Mekong Delta & 0.014 & 0.006 & -0.023 & 0.002 \\
\hline Constant & $0.417 * * *$ & 0.096 & 0.218 & 0.617 \\
\hline F-test & 0.000 & & & \\
\hline Rho & 0.772 & & & \\
\hline R-squared & 0.66 & & & \\
\hline No. of Observations & 133 & & & \\
\hline
\end{tabular}

Source: Author's calculation from World Bank (2009, 2015).

The results of this regression show that access to finance is the positive contributor of employment growth and this result is completely consistent with the literature review. In the case other factors keep unchanged if the possibility of access to finance increases by $1 \%$, the average employment growth rate will increase by $0.3 \%$. In reality, finance access is really important to the survival of enterprises, especially to SMEs because the economy of Vietnam is a bank-based market (Nguyen, 2014). However, there are many factors preventing Vietnamese SMEs from accessing finance, such as high collateral. 
However, this factor in this analysis is not statistically meaningful. This can be explained by the notion that besides collateral, the weaknesses of SMEs such as lack of specific business strategies, short-term vision, management skills, financial ability make SMEs difficult to get loans from banks rather than collateral (Nguyen, 2014). The variable year of firms causes the negative sign, which means that the older firms in Vietnam has witnessed the decline in the employment growth rate in the period 2009-2015, which is in line with the result of surveys conducted by VCCI in the years 2013 and 2015. In addition, the average number of monthly power outages was also not statistically significant and was not as expected. However, to avoid the bias in the evaluation, the author only focused on factors that have been negatively impacting SMEs, namely informal payments, time to deal with administrative procedures, and tax inspections.

Like many other studies mentioned in the literature review, in this study, informal payment, a specific manifestation of corruption, is also regarded as a serious obstacle for doing business in Vietnam, whereby the growth rate of firm's employment will increase by $2.5 \%$ if the informal payment decreases by $1 \%$. According to Corruption Perception Index of Transparency International in 2016, Vietnam ranks $113^{\text {th }}$ place out of 176 countries, which shows a state of serious corruption in Vietnam. Many entrepreneurs have to work hard to overcome barriers and administrative procedures created by corrupted officials, instead of putting this effort into performance and production. Moreover, corruption also weakens the positive influence of competition in the market. Specifically, competitiveness will not truly reflect the economic efficiency because low-capacity businesses that know how to deal with corruption will get more favorable policies which lead to more opportunities to develop than other businesses. In the case of a developing country in transition such as Vietnam, because the institutions are being perfected, state officials have many chances to act corrupt, especially in some extremely important fields such as customs, transport police, construction, and land management (World Bank \& The Government Inspectorate of Vietnam, 2013).

The institution quality of Vietnam, which is represented by variable "Time of Administrative Procedure" is also an obstacle to SMEs in Vietnam. Enterprises in 
Vietnam often face the changes in administrative procedures, such as in tax and in specialized law, such as social security. If the time senior managers need to deal with government regulations decreases by one hour a week while other factors remain stable, the employment growth rate will increase $1.3 \%$ on average. The longer time that a senior manager spends in dealing with regulations, the higher business cost that enterprise has to suffer. Furthermore, the long time for required regulations can show the complication of regulations which can make firms pay informally. Similarly, tax inspection can distort a firm's growth. If tax officials can reduce inspection by one time a year, the employment growth rate of firm will raise average $2.7 \%$. This result shows that tax administration in Vietnam is one of the most severe obstacles to firms.

\section{CONCLUSIONS AND POLICY RECOMMENDATIONS}

Based on the results of regression analysis, three business environment factors that negatively impacted SMEs in Vietnam in the period 2009-2015 were the informal payment, the institution quality, and tax inspections, while gaining more access to finance might help enterprises develop better. Tax inspections were perceived as the single most severe obstacles to firms' evolution. Therefore, more application of information technology in tax administration can bring great effects to tax reform. Because this application can reduce interaction between tax authorities and taxpayers, it can lead to the decrease in tax compliance costs and administrative costs.

From a policy perspective, development of efficient institutions that improve functions of the market is crucial for firm growth. Reforms that focus on cutting down the number of sub-licenses and reducing the administrative procedures could stimulate investment and competition for SMEs in Vietnam.

It is also important to implement policies that promote economic activities. The regression analysis performed in this study shows that increased access to finance is also a possible solution to nurture SMEs. Vietnam is a bank-based market, therefore most loans come from banks, and in order to increase the possibility of getting loans, SMEs should have a thorough business strategy: A long-run vision that can reduce the risks and 
meet banks' requirements. In addition, there are several organizations that address the financial bottlenecks to the expansion of SMEs. Organizations such as the Small and Medium Enterprise Development Fund (SMEDF), Credit Guarantee Fund (CGF) provide financial and/or non-financial aid, such as business plan preparation, tax consultation, etc. for development of SMEs. However, many SMEs are either not aware of alternative financial sources that are available to them or they have difficulties in accessing these sources. Hence, expanding the reach of support schemes of these organizations would lead to significant improvements in the growth prospects of SMEs in Vietnam.

In the end, corruption causes harm to the economy and creates risks for the whole society. However, the control of corruption is always difficult because when there is a reform to curb corruption, there is always a tendency to remain the status quo against the reform. As mentioned above, in Vietnam, there are many opportunities for state officials to corrupt, such as low salary for officials, complicated administrative procedures, and lack of supervision from society. Therefore, to prevent corruption, it is essential to reduce the opportunities to corrupt by: (i) Simplifying and rationalizing the regulatory loopholes by eliminating sub-licenses; and (ii) Increasing transparency by empowering technology in administrative procedures, especially in tax administration and customs to restrict direct meeting between officials and people.

\section{REFERENCES}

Aterido, R., \& Hallward-driemeier, C. P. (2009). Big constraints to small firms' growth: Business environment and employment growth across firms. Economic Development and Cultural Change, 59(2), 609-647.

Bartlett, W., \& Bukvic, V. (2001). Barriers to SME growth in Slovenia. MOCT-MOST: Economic Policy in Transitional Economies, 11(2), 135-151.

Baurer, L. I. (2005). Tax administrations and small and medium enterprises in developing countries. Washington D.C., USA: The World Bank.

Beck, T., Demirguc, K. A., \& Maksimovic, V. (2005). Financial and legal constraints to growth: Does firm size matter? The Journal of Finance, LX(1), 137-177.

Cecelski, E. (2004). Re-thinking gender and energy: Old and new directions (Discussion Paper). Retrieved from http://www.hedon.info/docs/RethinkingGenderAnd EnergyOldAndNewDirections.pdf. 
CIEM. (2016). Đặc điểm môi truờng kinh doanh ở Việt Nam: Kết quả điều tra doanh nghiệp nhỏ và vì̀a năm 2015. Retrieved from https://www.wider.unu.edu/ sites/default/files/SME2015-report-Vietnamese.pdf

Cooley, T. F., \& Quadrini, V. (2001). Financial markets and firm dynamics. American Economics Review, 91(5), 1286-1310.

Eifert, B., Gelb, A., \& Ramachandran, V. (2006). Business environment and comparative advantage in Africa: Evidence from the investment climate data (Working Paper No. 56). Retrieved from https://www.cgdev.org/files/2732_file_WP56_1_revis .pdf.

Fisman, R., \& Svensson, J. (2007). Are corruption and taxation really harmful to growth? Firm-level evidence. Journal of Development Economics, 83(1), 63-75.

Fjose, S., Grunfeld, L. A., \& Green, C. (2010). SMEs and growth in Sub-Saharan Africa. Sørkedalsveien, Norway: MENON Economics Publication.

Gonzalez, A., López-Córdova, E. J., \& Valladares, E. E. (2007). The incidence of graft on developing-country firms (Working Paper No. 4394). Retrieved from https://openknowledge.worldbank.org/bitstream/handle/10986/7529/wps4394.pd f? sequence $=1 \&$ isAllowed $=\mathrm{y}$.

Gujarati, D. N. (2003). Basic econometrics. New York, USA: Mc-Graw Hill Press.

Jauch, R. L., \& William, F. G. (1988). Strategic management and business policy. New York, USA: McGraw-Hill, Inc.

Kato, A., \& Sato, T. (2014). Greasing the wheels? The effect of corruption in regulated manufacturing sectors of India (Working Paper No. DP2014-07). Retrieved from http://www.rieb.kobe-u.ac.jp/academic/ra/dp/English/DP2014-07.pdf.

Kauffmann, C. (2005). Financing SMEs in Africa. Policy Insights, (7), 1-4.

Krueger, A. O. (1993). The political economy of the rent-seeking society. The Economic Review, 64(3), 291-303.

Kumar, K. B., Rajan, R. G., \& Zingales, L. (1999). What determines firm size? (Working Paper No. 7208). Retrieved from http://www.nber.org/papers/w7208.pdf.

López, R. E., Thomas, V., \& Wang, Y. (2008). The quality of growth: Fiscal policies for better results (Working Paper No. 59625). Retrieved from https://openknowledge. worldbank.org/bitstream/handle/10986/28198/596250NWP01pub1B00quality1g rowth1wp.pdf? sequence=1\&isAllowed=y.

Mauro, P. (1995). Corruption and growth. The Quarterly Journal of Economics, 110(3), 681-712.

Nguyen, V. L. (2014). Tăng trưởng tín dụng ngân hàng đối với DNVVN ở Việt Nam trong điều kiện kinh tế vĩ mô bất ổn. (Luận án tiến sĩ), Học viện Ngân hàng, Việt Nam. Được truy lục từ gs.hvnh.edu.vn/upload/4989/fck/files/Luan\%20an(4).pdf.

Nguyen, A. (2016). Co thể doanh nghiệp chỉ 40 kg, gánh trên lung 3-4 tạ với hơn 7000 giấy phép con thì sống sao nổi. Được truy lục từ http://cafef.vn/co-the-doanh- 
nghiep-chi-40kg-ganh-tren-lung-3-4-ta-voi-7000-giay-phep-con-thi-song-saonoi-20160422164911128.chn.

Ojeka, S. A., \& Atawodi, O. W. (2012). Factors that affect tax compliance among small and medium enterprises in North Central Nigeria. International Journal of Business and Management, 7(52), 87-96.

Oscar, T. R. (2007). Panel data analysis: Fixed and random effects using Stata. Retrieved from https://www.princeton.edu/ otorres/Panel101.pdf.

Porter, M. (2010). The 2010 Vietnam competitiveness report. Hanoi, Vietnam: Thong Ke Publisher.

Scott, A., Darko, E., \& Lemma, A. (2014). How does electricity insecurity affect businesses in low and middle-income countries? Retrieved from https://www.odi. org/sites/odi.org.uk/files/odi-assets/publications-opinion-files/9425.pdf.

Seker, M., \& Correa, P. G. (2010). Obstacles to growth for small and medium enterprises in Turkey (Working Paper No. 5323). Retrieved from http://enterprisesurveys.org/ /media/FPDKM/EnterpriseSurveys/Documents/Research\%20Papers/Obstaclesto-Growth-in-Turkey.pdf.

Shaikh, S. (2010). Business Environment. New Delhi, India: Pearson Education.

UNDP. (2005). Energizing the millennium development goals: A guide to energy's roles in reducing poverty. Retrieved from http://content-ext.undp.org/aplaws_ publications/2679356/ENRG-MDG_Guide_all.pdf.

VCCI. (2008). Báo cáo thương niên doanh nghiệp Việt Nam 2008. Hà Nội, Việt Nam: NXB. Chính trị Quốc gia.

VCCI. (2015). Báo cáo thương niên doanh nghiệp Việt Nam 2014. Hà Nội, Việt Nam: VCCI.

Vial, V., \& Hanoteau, J. (2014). Grease or sand the wheel? The effect of individual bribe payments on aggregate productivity growth. Journal of Indonesian Economy and Business, 29(1), 1-16.

Vũ, T. T. A. (2015). Doanh nghiệp nhà nước không đủ năng lực đóng vai trò chủ đạo. Được truy lục từ http://www.thesaigontimes.vn/Home/thoisu/sukien/42114/ Doanh-nghiep-nha-nuoc-khong-du-nang-luc-dong-vai-tro-chu-dao.html

World Bank. (2000). Helping countries combat corruption: Progress at the World Bank since 1997. Washington, D.C., USA: The World Bank.

World Bank. (2005a). World development report 2005: A better investment climate for everyone. Oxford, UK: Oxford Publication.

World Bank. (2005b). Enterprise survey and indicator survey: Sampling methodology. Retrieved from http://www.enterprisesurveys.org.

World Bank. (2009). Vietnam's enterprise survey. Retrieved from http://microdata. worldbank.org/index.php/catalog/341. 
World Bank. (2014). Doing business 2015: Going beyond efficiency. Retrieved from http:// doingbusiness.org/ /media/wbg/doingbusiness/documents/ annual-reports /english/DB15-full-report.pdf.

World Bank. (2015). Vietnam's enterprise survey. Retrieved from http://microdata. worldbank.org/index.php/catalog/2664/study-description.

World Bank. (2016). Doing Busines 2016: Measuring regulatory quality and efficiency. Retrieved from http://www.doingbusiness.org/ /media/WBG/doingbusiness/ documents/annual-reports/english/db16-Full-Report.pdf.

World Bank, \& The Government Inspectorate of Vietnam. (2013). Corruption from the perspectives of citizens, enterprises, and public officials. Hanoi, Vietnam: National Political Publishing House.

Zhu, Y., Xinhua, W., \& Mike, P. W. (2012). Institution-based barriers to innovation in SMEs in China. Asia Pacific Journal of Management, 29(4), 1131-1142. 